\title{
EFFECT OF CANOPY MICROCLIMATE ON MERLOT (VITIS VINIFERA L.) GRAPE COMPOSITION
}

\author{
CANDAR, S. ${ }^{{ }^{*}}-$ KORKUTAL, I. ${ }^{2}-$ BAHAR, E. $^{2}$ \\ ${ }^{1}$ Tekirdă̆ Viticulture Research Institute, 59100 Tekirdă̆, Turkey \\ ${ }^{2}$ Department of Horticulture, Agricultural Faculty, Namik Kemal University, 59030 Tekirdag, \\ Turkey \\ *Corresponding author \\ e-mail:serkan.candar@tarimorman.gov.tr
}

(Received 14 $4^{\text {th }}$ Jul 2019; accepted $15^{\text {th }}$ Nov 2019)

\begin{abstract}
The objective of this work was to evaluate the effect of different canopy management practices on canopy microclimate and consequently berry quality components of the Merlot (Vitis vinifera L.) grape variety. Different microclimate effects were created by the limitations of $1 \mathrm{~m}, 1.25 \mathrm{~m}$ and $1.5 \mathrm{~m}$ main shoot lengths and full lateral shoots (FLS), half lateral shoots (HLS) and no lateral shoots (NLS). Microclimatic data was gathered by the sensors placed in the canopies of FLS, HLS and NLS vines located under the $1.25 \mathrm{~m}$ main shoot length parcel. In the study, total soluble solids content, titratable acidity, $\mathrm{pH}$, total phenolic content, total anthocyanin content, total tannin content, tartaric and malic acid content and potassium content in the juice were evaluated as the biochemical quality properties. The results of two years indicated that canopy microclimate arrangements may provide some manipulation on grape berry quality according to the vegetation period's climate characteristics and the desired target quality within limits of macro-meso climate effects.
\end{abstract}

Keywords: canopy management, summer pruning, phenolic content, anthocyanins, must quality

\section{Introduction}

Canopy management applications may have some adverse affects on the physiological properties of the vine as a result of the isolation of vine-canopy microclimate from environmental factors, such as temperature, light exposure, atmospheric humidity and air flow when they are not considered as serious cultivation practices. As the green pruning is not performed according to a methodology, appropriate to the characteristics of the vegetation period, the production/consumption balance may deteriorate in the physiological sense. Exposure of clusters to direct sunlight can also cause physical damage and deterioration of the chemical structure of the berries under high temperatures.

There is an important amount of knowledge about the relationship between microclimate parameters and quality components. Temperature is the main factor controlling growth and quality. Improvements in criteria such as total phenolic, anthocyanin content, main components of sensory characteristics of wines, aroma, color and taste can be seen at certain stress levels (Matthews et al., 1990). Similarly, the positive effects of polyphenol components and antioxidant activity on human health can be increased (German and Walzem, 2000; Dixon et al., 2005). However, high evaporative demand during high temperature periods and growing period may play a role in limiting yield, berry wine quality (Escalona et al., 1999; Chaves et al., 2007). This can lead to wine acidity problems by reducing the coloration and sugar accumulation of the berry (Medrano et al., 2003; Romero et al., 2010). In addition, under the total intertwined impact of environmental stress factors, instant 
photosynthesis reduction and risky losses in total carbon assimilation and even total canopy area may occur (Flexas et al., 1998, 2002; Maroco et al., 2002; Santos et al., 2007). The effect of light exposure on the vine (often not easily separated from temperature) is observed in physiological activities, shoot development and wooding, berry formation, fall, ripening processes and quality (Reynolds et al., 1986; Crippen and Morrison, 1986; Rojas-Lara and Morrison, 1989; Schubert et al., 1996; Haselgrove et al., 2000; Bertamini and Nedunchezhian, 2003; Spayd et al., 2011; Profio et al., 2011).

The effects of the climate crisis that are going on beyond the traditional interaction between viticulture and climate are also discussed by researchers in a multi-dimensional context (Schultz, 2000; Nemani et al., 2001; Jones, 2007; Webb et al., 2008; Fraga et al., 2012; Vrsic and Vodovnik, 2012; Donat et al., 2013). As climate change is inevitable (Carbonneau and Bahar, 2009), different canopy management practices are an important tool for managing and adapting this process (This et al., 2006; Olsen et al., 2011). Canopy microclimate arrangements may provide some manipulation on grape berry and wine quality within limits of macro-meso climate affects and climate crisis.

There is a close relationship between the quality of grapes and wine and the composition of the berries. Therefore, quality depends on many components such as grape varieties, total soluble solids (TSS), organic acids, $\mathrm{pH}$, phenolic substances, the thickness of the berry skin, the berry skin area, the ratio of the skin area/berry volume, the effect of ecological conditions, maturity time, the effect of diseases, rootstock and canopy management (Ribéreau-Gayon et al., 2000; Blouin and Guimberteau, 2000; Keller, 2010; Treutter, 2010).

The aim of the present study was to provide a better understanding of the effect of different canopy management practices on canopy microclimate and consequently berry quality components.

\section{Materials and methods}

\section{Location, plant material and trial design}

The two-year study (2014 and 2015) was conducted at the Tekirdağ Viticulture Research Institute, located in Northwest of Turkey (in Thrace), within the coordinates $40.969184^{\circ} \mathrm{N}-40.973562^{\circ} \mathrm{N}$ latitudes and $27.461911^{\circ} \mathrm{E}-27.477504^{\circ} \mathrm{E}$. longitudes. The climate of Tekirdağ, is defined as a transitional climate among the Continental climate, the Black Sea climate and the Mediterranean climate with an average annual temperature of $14{ }^{\circ} \mathrm{C}$, annual precipitation of $581.80 \mathrm{~mm}$ and 1887.00 growing daydegree Winkler Index for the years of 1939-2017 period. The altitude of vineyard was approximately $36 \mathrm{~m}$ and was approximately $4 \mathrm{~km}$ away from the sea. Merlot/5BB grafting combination 12-13 years old vines were oriented North-South on a high groundwater and clay-loam soil. Vines were arranged in a between-row and within-row spacing of $2.5 \times 1.5 \mathrm{~m}$ respectively. Double Guyot training vines pruned $16-18$ bud per vine.

Different microclimate effects were created by the limitations of $1 \mathrm{~m}, 1.25 \mathrm{~m}$ and $1.5 \mathrm{~m}$ main shoot lengths while they reached 170-180 cm (EL 31-33) shoot lengths for main parcels. Lateral shoot applications were sub-parcels which created by full lateral shoots (6-7 leaves), half lateral shoots (3-4 leaves) and no lateral shoots (no leaf) performed in verasion (EL 35) according to Lorenz et al. (1995). Both applications were kept at the same length until the harvest period. 
Data was gathered from meteorological stations located in Tekirdag Viticulture Research Institute in order to determine mesoclimatic and microclimatic conditions. A climate station which located $2 \mathrm{~m}$ high from ground was used to collect mesoclimatic data reflecting the general climatic characteristics of the vineyard. Mesoclimatic measurements; temperature, relative humidity, light intensity, wind speed, total precipitation and microclimatic measurements from the insides of the vine canopies which were the descriptive features such as temperature, relative humidity, light intensity, wind speed and leaf wetness were monitored during the years 2014 and 2015.

Microclimatic data sensors were placed in the canopies of full lateral shoot (FLS, 6-7 leaves), half lateral shoot (HLS, 3-4 leaves) and no lateral shoot (NLS) sub-parcel vines that located under $1.25 \mathrm{~m}$ main shoot length main parcel, from the beginning of the vegetation period and measurements were continued until the end of harvest by SHT11 Temperature, humidity and leaf wetness sensor module (Sensirion AG, Switzerland) for temperature, humidity and leaf wetness. TEMT 6000 light sensor (Vishay Intertechnology, Inc., Germany) and WGR800 wind sensor (Oregon scientific, USA) readings were gathered by a cloud based datalogger (Mrme AR-GE Bilişim, Turkey). The 5 min averages of two-second readings from each sensor derived as the station's hourly value.

The inside of the three canopies were equipped with one temperature, humidity, leaf wetness, wind and four light intensity sensors (Fig. 1). Also light intensity sensors positioned two each around cluster zone and center canopy. The wind sensor in the canopy is enclosed in a suitably sized wireframe that does not stop the wind flow to prevent contact with leaves and shoots. Maintenance and control of the sensors placed inside vines were done regularly to avoid any data loses after cultivation practices such as spraying, green pruning etc.
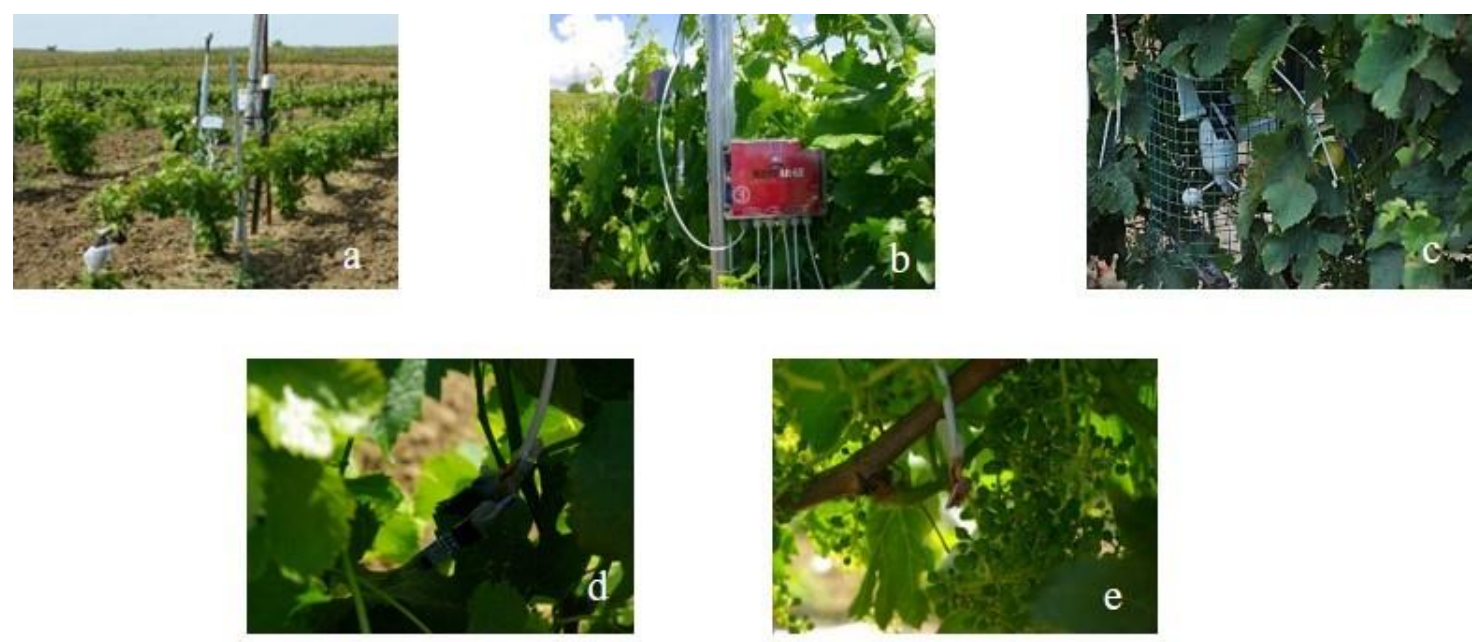

Figure 1. Placing of different sensors and loggers in vineyard (a) main electric and GSM unity, (b) cloud based datalogger, (c) wind sensor, (d) temperature, humidity, leaf wetness, (e) light sensor

Although the data received from all of the above sensors for all growing process, only outputs of temperature and light intensity effects between verasion-harvest period are evaluated in this publication due to the important effects on must composition. 
Despite the equal number of (16) buds left in the winter pruning, the plants that disrupt homogeneity in the number of shoots and bunches were balanced when the shoots reached an average length of 30-40 cm (EL 15-17) or excluded from the trial. Standard cultural practices in the region were applied to all treatments during research. The vines data taken were selected from the same development period and with the approximate charge and those without spaces.

\section{Must composition}

The total soluble solids (\%), $\mathrm{pH}$, total acidity ( $\mathrm{g} / \mathrm{L}$ of tartaric acid), and the concentration of tartaric acid $(\mathrm{g} / \mathrm{L})$, malic acid $(\mathrm{g} / \mathrm{L})$ and potassium $(\mathrm{mg} / \mathrm{L})$ in must from grapes collected from each experimental replication at the harvest date was determined using the official methods of the Organisation Internationale de la Vigne et du Vin (OIV) (OIV, 2012). Also, total phenolic content $(\mathrm{mg} / \mathrm{kg})$, total anthocyanin content $(\mathrm{mg} / \mathrm{kg})$ and total tannin content $(\mathrm{g} / \mathrm{kg})$ were found out as biochemical analysis (AOAC, 1998; Waterhouse, 2002).

\section{Statistical analysis}

The experiment consisted with combination of 3 different main shoot length and 3 different lateral shoot length applications. A randomized block design was used with 3 replications of a total of 108 vines under 27 parcels. JMP 13.2.0 statistical program was used for determining of differences in applications and years. In order to determine differences in findings, LSD test was used at 5\% significance level.

\section{Results and discussion}

\section{Phenological development stages}

As a result of the phenological observations made throughout the trial, the day green shoot tips seen clearly in the buds was 02.04.2014 (91 ${ }^{\text {st }}$ calendar day) for the year 2014, for 2015 it was observed as 12.04.2015 (101 ${ }^{\text {st }}$ calendar day) (Table 1).

Table 1. Phenological development stages of Merlot variety during the experiment years

\begin{tabular}{c|c|c|c}
\hline Budburst (EL 04-07) & Flowering (EL 23-25) & Verasion (EL 35) & Harvest (EL 38) \\
\hline 02.04 .2014 & 29.05 .2014 & 30.07 .2014 & 16.09 .2014 \\
12.04 .2015 & 28.05 .2015 & 01.08 .2015 & 05.10 .2015 \\
\hline
\end{tabular}

\section{Climatic conditions}

General climatic conditions of 2014-2015 years'

While the average temperature was recorded as $16.08{ }^{\circ} \mathrm{C}$ in 2014 and $16.00{ }^{\circ} \mathrm{C}$ in 2015, the average temperature in Tekirdağ province for long years (1939-2017) was $14{ }^{\circ} \mathrm{C}$. 2014 was an extraordinary year in terms of precipitation. The annual total precipitation was $770.50 \mathrm{~mm}$, which is significantly higher than the average of $589.10 \mathrm{~mm}$ for long years. Vegetation period precipitation was also remarkable with $475.20 \mathrm{~mm}$ which is also above $139.00 \mathrm{~mm}$ average of long years. In 2015, the total annual precipitation was $507.90 \mathrm{~mm}$ and $187.40 \mathrm{~mm}$ precipitation in the vegetation 
period is around the average for long years. Due to the general characteristics of 2014 , light exposure (PFD) and wind speed were lower than 2015 in 2014 both during the year and vegetation period. Average proportional humidity was also higher for year and vegetation period in 2014.

In 2014, the maximum temperature was measured as $33.50{ }^{\circ} \mathrm{C}$, while the lowest temperature was recorded as $16.10{ }^{\circ} \mathrm{C}$. Also verasion-harvest periot average temperature ranged from 22.00 to $27.60{ }^{\circ} \mathrm{C}$. The light intensity (PFD) ranged between $62.53 \mu \mathrm{mol} \mathrm{m} / \mathrm{s}$ and $1976.27 \mu \mathrm{mol} \mathrm{m} / \mathrm{sec}$, with an average of $1134.53 \mu \mathrm{mol} \mathrm{m}^{2} / \mathrm{s}$ in 2014.

In 2015, the highest temperature was recorded as $39.70{ }^{\circ} \mathrm{C}$ and the lowest temperature was $12.30{ }^{\circ} \mathrm{C}$ and the average temperature was between 14.30 and $29.00{ }^{\circ} \mathrm{C}$. In the same period, while PFD measurements ranged from $44.37 \mu \mathrm{mol} \mathrm{m} / \mathrm{s}$ to $1894.88 \mu \mathrm{mol} \mathrm{m} / \mathrm{sec}$, the average period was recorded as $1042.43 \mu \mathrm{mol} \mathrm{m} / \mathrm{s}$ (Fig. 2).

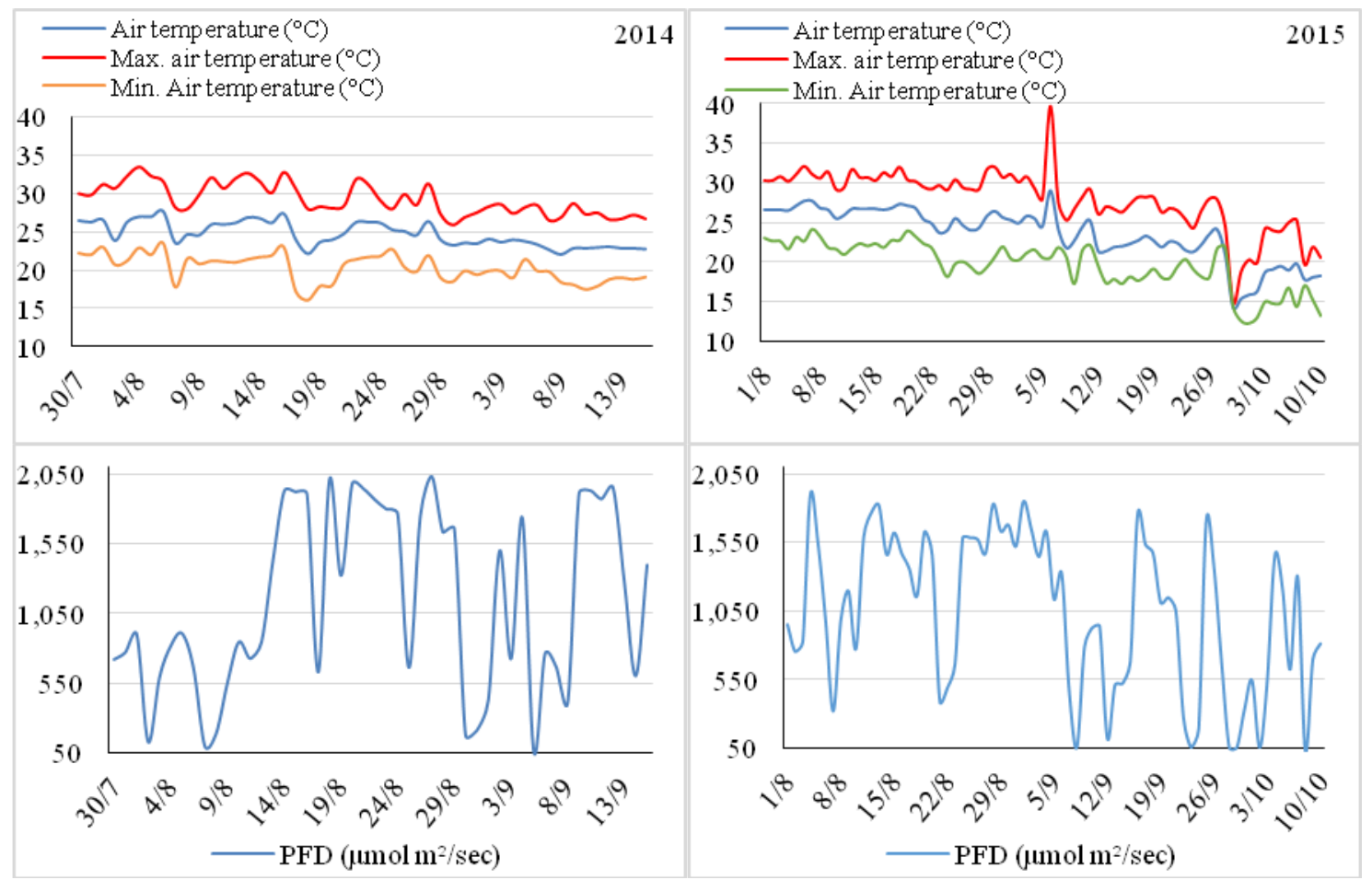

Figure 2. General temperature and light intensity data of verasion-harvest period in year 2014 and 2015

\section{Microclimatic conditions inside canopies between verasion and harvest period}

Temperature related microclimatic assessments were made for 5 critical intervals per hours/day in terms of the duration of exposure for lateral shoot applications. In addition, the average, lowest and highest temperatures in the related phenological periods were determined.

All lateral shoot leaf removal applications were completed in the first week of August in both years and targeted canopy architectures were created. The most remarkable issue in terms of temperatures for 2014, while the highest temperature in the whole of the vineyard was recorded as $30.10{ }^{\circ} \mathrm{C}$ in August and $27.70{ }^{\circ} \mathrm{C}$ in AugustSeptember mean, the temperature of the canopy was exposed to temperatures in the 
range of $30-35{ }^{\circ} \mathrm{C}$ and over $35{ }^{\circ} \mathrm{C}$ in all lateral shoot applications. It is noteworthy that temperatures below $20^{\circ} \mathrm{C}$ in 2015 are 3-4 times more than in 2014. In both years; temperatures above $35^{\circ} \mathrm{C}$ were observed in the NLS application for the longest period, while the temperature above $30{ }^{\circ} \mathrm{C}$ was measured at the maximum HLS application. It was observed that in the period between verasion and harvest; most seen temperature range was between 20 and $25{ }^{\circ} \mathrm{C}$ in 2014 and 2015. Another remarkable point is that the FLS application remains the longest at temperatures below $20^{\circ} \mathrm{C}$. Temperatures above $35^{\circ} \mathrm{C}$ were observed for longer periods with the removal of the lateral leaves (Table 2). The positive and negative aspects of this phenomenon will be mentioned in the headings on must analytical analysis.

Table 2. Verasion-harvest period temperature intervals in canopy (hours/day)

\begin{tabular}{c|c|c|c|c|c|c|c|c|c|c}
\hline \multirow{2}{*}{ Verasion-harvest period } & \multicolumn{2}{|c|}{$\leq \mathbf{2 0}{ }^{\circ} \mathbf{C}$} & \multicolumn{2}{|c|}{$\mathbf{2 0 - 2 5}{ }^{\circ} \mathbf{C}$} & \multicolumn{2}{|c|}{$\mathbf{2 5 - 3 0}{ }^{\circ} \mathbf{C}$} & \multicolumn{2}{|c|}{$\mathbf{3 0 - 3 5}{ }^{\circ} \mathbf{C}$} & \multicolumn{2}{|c}{$\geq \mathbf{3 5}^{\circ} \mathbf{C}$} \\
\cline { 2 - 11 } & $\mathbf{2 0 1 4}$ & $\mathbf{2 0 1 5}$ & $\mathbf{2 0 1 4}$ & $\mathbf{2 0 1 5}$ & $\mathbf{2 0 1 4}$ & $\mathbf{2 0 1 5}$ & $\mathbf{2 0 1 4}$ & $\mathbf{2 0 1 5}$ & $\mathbf{2 0 1 4}$ & $\mathbf{2 0 1 5}$ \\
\hline NLS & 2.45 & 6.18 & 9.34 & 8.14 & 3.44 & 3.19 & 4.34 & 3.43 & 3.23 & 2.25 \\
HLS & 2.36 & 5.49 & 8.55 & 6.49 & 3.53 & 4.20 & 8.1 & 5.51 & 0.27 & 1.11 \\
FLS & 2.53 & 8.29 & 7.41 & 6.15 & 4.47 & 5.11 & 6.39 & 3.20 & 0.16 & 0.43 \\
\hline
\end{tabular}

NLS, HLS, and FLS represent no lateral shoots (no leaf), half lateral shoots (3-4 leaves) full lateral shoots (6-7 leaves)

While the mean temperature in the canopy ranged between 26.16 and $26.92{ }^{\circ} \mathrm{C}$ in of 2014 verasion-harvest period, the average outside canopy temperature at $2 \mathrm{~m}$ was recorded as $23.02{ }^{\circ} \mathrm{C}$. In 2015 verasion-harvest period in canopy mean temperature was changed between 23.36 and $25.26^{\circ} \mathrm{C}$ and average temperature at $2 \mathrm{~m}$ outside canopy was recorded as $24.40^{\circ} \mathrm{C}$.

During the same period in 2014 , the highest average temperature was $27.70{ }^{\circ} \mathrm{C}$ at $2 \mathrm{~m}$, while the maximum high temperature was $46.06^{\circ} \mathrm{C}$ (NLS) and the lowest high temperature was $37.80{ }^{\circ} \mathrm{C}$ (HLS). The highest average temperature was $35.90{ }^{\circ} \mathrm{C}$ at $2 \mathrm{~m}$ and in canopy measurement was found $49.77^{\circ} \mathrm{C}$ for NLS application and $42.77{ }^{\circ} \mathrm{C}$ for HLS application in 2015.

In canopy low temperature averages range between $14.46{ }^{\circ} \mathrm{C}$ and $15.70{ }^{\circ} \mathrm{C}$ and $2 \mathrm{~m}$ was recorded as $18.70{ }^{\circ} \mathrm{C}$ in year of 2014. Two meters low temperature averages were also recorded as $15.40{ }^{\circ} \mathrm{C}$ in 2015 , and ranged between $5.12{ }^{\circ} \mathrm{C}$ (NLS) and $11.18{ }^{\circ} \mathrm{C}$ (FLS) in canopy (Table 3).

In both years, outside canopy low temperatures are higher than in canopy low temperatures. Cold weather is trapped inside the canopy at night. In summary, there are no significant differences between the inside and outside of the canopy in terms of average temperatures, but dramatic differences can be observed at low and high temperatures. In the case of high temperatures, it is observed that in canopy temperatures have increased by $18.36^{\circ} \mathrm{C}$ for 2014 and $13.87{ }^{\circ} \mathrm{C}$ in 2015 for the NLS application due to loss of shade effect created by lateral shoot leaves.

\section{Light intensity averages based on phenological periods}

The light intensity measurements were evaluated by calculating the mean data from the canopy microclimates and the data mean obtained from the overall vineyard according to phenological periods. 
In 2014 Verasion-harvest period NLS, HLS and FLS applications were measured as $51.29 \mu \mathrm{mol} \mathrm{m} / \mathrm{sec}, 45.75 \mu \mathrm{mol} \mathrm{m} / \mathrm{s}$ and $30.30 \mu \mathrm{mol} \mathrm{m} / \mathrm{sec}$, respectively and the outside canopy light at $2 \mathrm{~m}$ level was recorded as $1155.14 \mu \mathrm{mol} \mathrm{m} / \mathrm{s}$ (Table 4). In this period, it was seen that the total light intensity that reached to the whole of the vineyard could only reach the canopy center and clusters in 4.44\% NLS application, $3.96 \%$ in HLS application and $2.62 \%$ in FLS application (Fig. 3).

Table 3. In and outside canopy temperature averages according to the applications between the periods of verasion-harvest in 2014 and $2015\left({ }^{\circ} \mathrm{C}\right)$

\begin{tabular}{c|c|c|c|c|c|c}
\hline \multirow{2}{*}{$\begin{array}{c}\text { Verasion-harvest } \\
\text { period }\end{array}$} & \multicolumn{2}{|c|}{ Max. temperature $\left({ }^{\circ} \mathbf{C}\right)$} & \multicolumn{2}{|c|}{ Mean temperature $\left({ }^{\circ} \mathbf{C}\right)$} & \multicolumn{2}{|c}{ Min. temperature $\left({ }^{\circ} \mathbf{C}\right)$} \\
\cline { 2 - 7 } & $\mathbf{2 0 1 4}$ & $\mathbf{2 0 1 5}$ & $\mathbf{2 0 1 4}$ & $\mathbf{2 0 1 5}$ & $\mathbf{2 0 1 4}$ & $\mathbf{2 0 1 5}$ \\
\hline NLS & 46.06 & 49.77 & 26.92 & 24.83 & 15.70 & 5.12 \\
HLS & 37.80 & 42.77 & 26.42 & 25.26 & 15.58 & 10.36 \\
FLS & 41.91 & 43.33 & 26.16 & 23.36 & 14.46 & 11.18 \\
\hline Outside canopy 2 m. & 27.70 & 35.90 & 23.02 & 24.40 & 18.70 & 15.40 \\
\hline
\end{tabular}

NLS, HLS, and FLS represent no lateral shoots (no leaf), half lateral shoots (3-4 leaves) full lateral shoots (6-7 leaves)

Table 4. In and outside canopy light intensity averages according to the applications between the periods of verasion-harvest in 2014 and $2015(\mu \mathrm{mol} \mathrm{m} / \mathrm{s})$

\begin{tabular}{c|c|c}
\hline Verasion-harvest period & $\mathbf{2 0 1 4}$ & $\mathbf{2 0 1 5}$ \\
\hline NLS & 51.29 & 28.71 \\
HLS & 45.75 & 21.43 \\
FLS & 30.30 & 23.05 \\
\hline Outside canopy $2 \mathrm{~m}$. & 1155.14 & 1068.69 \\
\hline
\end{tabular}

NLS, HLS, and FLS represent no lateral shoots (no leaf), half lateral shoots (3-4 leaves) full lateral shoots (6-7 leaves)

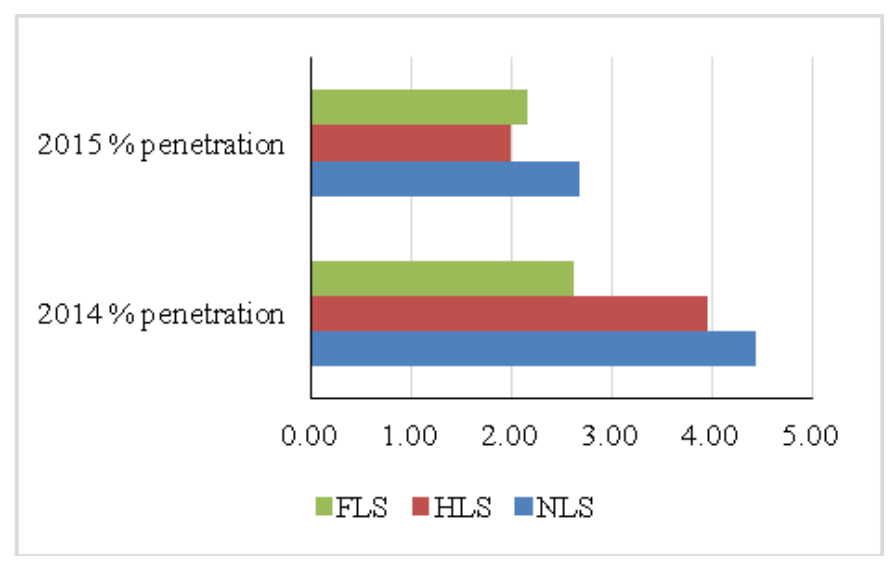

Figure 3. Penetration percentage of light into the canopy from outside in version-harvest period in years' 2014 and 2015

Although 2015 was a year with a higher number of cloudless skies compared to the previous year, the late harvest date led to a decrease in the overall average light 
intensity across the vineyard. Thus, the average light intensity of the outside canopy at $2 \mathrm{~m}$ was measured as $1068.69 \mu \mathrm{mol} \mathrm{m} / \mathrm{s}$ while the application of NLS was $28.71 \mu \mathrm{mol} \mathrm{m} / \mathrm{s}$, HLS application was $21.43 \mu \mathrm{mol} \mathrm{m} / \mathrm{s}$ and FLS application was $23.05 \mu \mathrm{mol} \mathrm{m} / \mathrm{s}$. The penetration rates into the canopy were calculated as $2.19 \%$ for NLS application, $2.01 \%$ for HLS application and $2.16 \%$ for FLS application (Fig. 3). In addition, the damage to the leaves and the relative reduction in total leaf area due to the severe Plasmopara viticola outbreak in 2014 may have resulted in higher light penetration into the canopy this year. Although not statistically significant, this phenomenon is supported by the decrease in yield and the increase in anthocyanin amounts this year.

Although these values appear to be very low, Smart et al. (1990) stated that approximately only $6 \%$ of the intense light from the sun is absorbed by the leaf, and that when the intense canopy formation is seen in the grapevine, the light penetration into the canopy is very low and only $1 \%$ of the upper leaves are able to be illuminated. Escalona et al. (2003) also have obtained similar results in double-cordon trained Monte Negro grapes from measurements of outer and inner surfaces of canopies. On the other hand, in Taiz and Zeiger (2010), indicated that only 5\% of the total energy presence was used in carbohydrate production while explaining the process of converting solar energy into leaves by carbohydrates.

\section{Must analytical analyzes}

\section{Yield (kg per vine)}

As stated before, in both years, 16 buds per vine were left in winter prunings, and shoots and clusters were equalized when the shoots reached $30-40 \mathrm{~cm}$ in length. Thus, the differences between the yield values were not statistically significant. Yield values were seen the lowest for NLS application with $4.60 \mathrm{~kg} / \mathrm{vine}$ and highest for FLS application with $5.00 \mathrm{~kg} / \mathrm{vine}$.

\section{Total soluble solids (\%)}

As known, the amount of sugar in the berry is one of the most important components of industrial maturity. While the effects of lateral shoot applications were found to be statistically significant in both years, differences in main shoot practices were found to be insignificant in terms of TSS values. In the average of two years, $1.25 \mathrm{~m}$ main shoot length application reached $21.88 \%$ highest TSS quantity while FLS application remained at $21.67 \%$. Differences in years averages were insignificant (Table 5).

It is observed that the application of NLS in water-soluble dry matter gives different results in both years. In 2014, the extreme rainfall and high proportional moisture occurring during the vegetation period affected the physiological activity positively in the application of full-fledged seat shoot and accelerated the availability of photosynthesis and hence the accumulation of dry matter throughout the vine. Under the relatively hot and dry conditions of 2015, the microclimate, in which the NLS application was affected, in particular in terms of high temperatures, slowed down the accumulation of TSS.

Therefore, it can be seen that the manipulations made at the right time and in the right way on the canopies provide options for the struggle against the negativity caused by the general climate characteristics. 


\section{Total acidity $(g / L)$}

The effects of different main and lateral shoot applications on total acidity were found to be statistically significant in 2014 and for the mean of two years in terms of lateral shoot applications, whereas in 2015 the differences were not significant. At the two-year average, the HLS and FLS applications were in the same statistical class with higher values, while the NLS application created another statistical class with lower total acidity (Table 5).

Table 5. Effects of main shoot and lateral shoot treatments on total soluble solids, total acidity and $\mathrm{pH}$

\begin{tabular}{c|c|c|c|c|c|c|c|c|c}
\hline \multirow{2}{*}{ Treatments } & \multicolumn{3}{|c|}{$\mathbf{2 0 1 4}$} & \multicolumn{3}{|c|}{$\mathbf{2 0 1 5}$} & \multicolumn{3}{|c}{ Mean of years } \\
\cline { 2 - 10 } & $\begin{array}{c}\text { TSS } \\
(\mathbf{\%})\end{array}$ & $\begin{array}{c}\text { Total } \\
\text { acidity }(\mathbf{g} / \mathbf{L})\end{array}$ & $\mathbf{p H}$ & $\mathbf{T S S}(\boldsymbol{\%})$ & $\begin{array}{c}\text { Total } \\
\text { acidity }(\mathbf{g} / \mathbf{L})\end{array}$ & $\mathbf{p H}$ & $\begin{array}{c}\text { TSS } \\
(\mathbf{\%})\end{array}$ & $\begin{array}{c}\text { Total acidity } \\
(\mathbf{g} / \mathbf{L})\end{array}$ & $\mathbf{p H}$ \\
\hline $1 \mathrm{~m}$ & 20.97 & 7.45 & 3.54 & 22.42 & 5.85 & 3.75 & 21.70 & 6.65 & 3.65 \\
$1.25 \mathrm{~m}$ & 20.97 & 7.53 & 3.54 & 22.80 & 5.83 & 3.73 & 21.88 & 6.68 & 3.63 \\
$1.5 \mathrm{~m}$ & 20.86 & 7.56 & 3.53 & 22.75 & 5.90 & 3.77 & 21.81 & 6.73 & 3.65 \\
$\mathrm{NLS}$ & $21.31^{a}$ & $7.13^{b}$ & $3.58^{a}$ & $22.42^{b}$ & 5.78 & 3.75 & 21.86 & $6.45^{b}$ & $3.66^{\mathrm{a}}$ \\
$\mathrm{HLS}$ & $20.84^{b}$ & $7.61^{a}$ & $3.54^{b}$ & $22.86^{a}$ & 5.86 & 3.75 & 21.85 & $6.74^{a}$ & $3.65^{\mathrm{ab}}$ \\
FLS & $20.66^{b}$ & $7.80^{\mathrm{a}}$ & $3.50^{\mathrm{c}}$ & $22.68^{a b}$ & 5.93 & 3.75 & 21.67 & $6.86^{a}$ & $3.62^{\mathrm{b}}$ \\
YME & $20.94^{B}$ & $7.51^{A}$ & $3.54^{B}$ & $22.65^{A}$ & $5.86^{B}$ & $3.75^{A}$ & & & \\
\hline MSME LSD $_{0.05}$ & n.s. & n.s. & n.s. & n.s. & n.s. & n.s. & n.s. & n.s. & n.s. \\
LSME LSD $_{0.05}$ & 0.383 & 0.273 & 0.034 & 0.343 & n.s. & n.s. & n.s. & 0.219 & 0.023 \\
YME LSD $_{0.05}$ & 0.234 & 0.180 & 0.019 & 0.234 & 0.180 & 0.019 & & & \\
\hline
\end{tabular}

NLS, HLS, and FLS represent no lateral shoots (no leaf), half lateral shoots (3-4 leaves) full lateral shoots (6-7 leaves). MSME means main shoot main effect, LSME means lateral shoot main effect and YME means year main effect. Different lowercase superscript letters in same column and uppercase letters in same line represent statistically significant differences between means at $p<0.05$ according to least significant difference test. n.s. means not significant

The most significant relationship between temperature and berry quality appears by reduction of organic acid concentration in berry with high temperatures (Kliewer, 1973).

Tartaric and malic acids are the predominant organic acids which are effective in all stages of berry development and cause significant effects on acidity and $\mathrm{pH}$ (Morris et al., 1983). In particular, the malate is stored in berries until the verasion period as a potential source for the carbon demand in the maturation process (Ruffner, 1982). In this period, the decrease in malic acid decreases the total acidity and balances the sugar and acid ratios (Kliewer, 1965). The decrease in titratable acid levels for 2014 and 2015 was directly proportional to the daily exposure time at temperatures between $20-25^{\circ} \mathrm{C}$. At temperatures near $30{ }^{\circ} \mathrm{C}$, seems to reduce the consumption of malic acid by inhibiting photosynthesis. Sweetman et al. (2014) states that enzymes and metabolic pathways that are effective in regulating organic acids during berry growth and development should be further investigated, especially in temperature rise and day/night temperature changes. On the other hand, the increase in the main shoot length caused an increase in titratable acid in years. According to a different study in the same location; Although it is not statistically significant, the main shoot length increase leads to a decrease in total acidity (Yasasin et al., 2018). 
$p H$

$\mathrm{Ph}$ values were found to be very close among the applications in 2015. In 2014 and the average of years, the NLS application reached the highest values and created a different statistical class. Thus, it can be said that in the years of unusual precipitation in vegetation period such as 2014, lateral shoot applications made a difference (Table 5).

\section{Total anthocyanin $(\mathrm{mg} / \mathrm{kg})$}

When total anthocyanin contents of grape varieties were examined, it was determined that the highest mean of total anthocyanin content was obtained from NLS application in 2014 (Table 6). The amount of high anthocyanin in the lateral shoot applications in both years between verasion harvest period was observed to be proportional to the time spent in $20-25{ }^{\circ} \mathrm{C}$ temperature range. But similar relationships were not determined at temperatures above $30{ }^{\circ} \mathrm{C}$ as found by Kliewer (1970), Kataoka et al. (1984), Mori et al. (2004), Tomana et al. (1979) or in Yamane et al. (2006) for the night temperatures below $20{ }^{\circ} \mathrm{C}$. Maybe, the lower number of berries in cluster, lower berry fresh weights and lower leaves of $\mathrm{pH}$ and factors like higher skin/flesh ratio and acidity in 2014 (data not shown) may have appeared as more important factors than temperature and rainfall.

In our study, it is seen that the increasing stress tendency caused higher anthocyanin levels in mean of years with increasing main shoot lengths, but not statistically. According to Yasasin et al. (2018), although it is not statistically significant, the total amount of anthocyanin in the main shoot length of $1.5 \mathrm{~m}$ is higher than the $1 \mathrm{~m}$ main shoot length.

Observing the direct effects of canopy management practices on the total amount of anthocyanins is quite difficult, as the mechanisms affecting the synthesis, deposition and degradation of anthocyanin are related to a number of factors. However, it is possible to influence the amount of anthocyanins by specific applications selected according to the prescribed climatic characteristics.

\section{Total tannin $(\mathrm{g} / \mathrm{kg})$}

In terms of tannins, there was no significant relationship between lateral and main shoot length applications and total tannin amount except for the different climatic characteristics of the two years (Table 6).

\section{Total phenolic $(\mathrm{mg} / \mathrm{kg})$}

The statistical significance differences between the applications for phenolic substances were only seen in 2014 . The highest phenolic substance content was found in the application of NLS (Table 6). Roby et al. (2004) and Chacon et al. (2009) reported that increased water stress increases the total phenolic content. In our study, it is seen that the relationship with the increased main shoot length did not significantly affect the total phenolic substance on the basis of years or years. However, it should be kept in mind that water stress did not occur at the levels that can be considered significant in the years when the trial was conducted. The increase in light intensity level and the relative increase in photosynthesis rates due to the removal of all lateral leaves under the effect of the climate conditions of 2014 is thought to have led to this increase. 
Table 6. Effects of main shoot and lateral shoot treatments on total anthocyanin, total tannins and total phenolics

\begin{tabular}{|c|c|c|c|c|c|c|c|c|c|}
\hline \multirow[b]{2}{*}{ Treatments } & \multicolumn{3}{|c|}{2014} & \multicolumn{3}{|c|}{2015} & \multicolumn{3}{|c|}{ Mean of years } \\
\hline & $\begin{array}{c}\text { Total } \\
\text { anthocyanin } \\
(\mathrm{mg} / \mathrm{kg})\end{array}$ & $\begin{array}{c}\text { Total } \\
\text { tannins } \\
\text { (g/kg) }\end{array}$ & $\begin{array}{c}\text { Total } \\
\text { phenolics } \\
(\mathrm{mg} / \mathrm{kg})\end{array}$ & $\begin{array}{c}\text { Total } \\
\text { anthocyanin } \\
(\mathrm{mg} / \mathrm{kg})\end{array}$ & $\begin{array}{c}\text { Total } \\
\text { tannins } \\
(\mathrm{g} / \mathrm{kg})\end{array}$ & $\begin{array}{c}\text { Total } \\
\text { phenolics } \\
(\mathbf{m g} / \mathrm{kg})\end{array}$ & $\begin{array}{c}\text { Total } \\
\text { anthocyanin } \\
(\mathrm{mg} / \mathrm{kg})\end{array}$ & $\begin{array}{c}\text { Total } \\
\text { tannins } \\
(\mathrm{g} / \mathrm{kg})\end{array}$ & $\begin{array}{c}\text { Total } \\
\text { phenolics } \\
(\mathrm{mg} / \mathrm{kg})\end{array}$ \\
\hline $1 \mathrm{~m}$ & 624.51 & 2.48 & 1810.27 & 472.64 & 4.22 & 2900.00 & 548.57 & 3.35 & 2355.14 \\
\hline $1.25 \mathrm{~m}$ & 628.62 & 2.68 & 1822.50 & 562.97 & 4.37 & 2985.83 & 595.79 & 3.52 & 2404.17 \\
\hline $1.5 \mathrm{~m}$ & 666.51 & 2.61 & 1966.38 & 572.29 & 4.39 & 3037.91 & 619.40 & 3.50 & 2502.15 \\
\hline NLS & $719.68^{a}$ & 2.75 & $2069.44^{a}$ & 574.57 & 4.35 & 3098.33 & $647.13^{a}$ & 3.55 & $2583.88^{a}$ \\
\hline HLS & $621.28^{a b}$ & 2.53 & $1742.77^{b}$ & 521.70 & 4.37 & 2909.44 & $571.49^{b}$ & 3.45 & $2326.45^{b}$ \\
\hline FLS & $578.68^{b}$ & 2.49 & $1786.94^{b}$ & 511.63 & 4.26 & 2915.97 & $545.16^{b}$ & 3.38 & $2351.45^{b}$ \\
\hline YME & $639.88^{A}$ & $2.59^{B}$ & $1866.38^{B}$ & $535.97^{B}$ & $4.32^{A}$ & $2974.58^{A}$ & & & \\
\hline $\mathrm{MSME} \mathrm{LSD}_{0.05}$ & n.s. & n.s. & n.s. & n.s. & n.s. & n.s. & n.s. & n.s. & n.s. \\
\hline $\mathrm{LSME} \mathrm{LSD}_{0.05}$ & 101.184 & n.s. & 230.276 & n.s. & n.s. & n.s. & 61.893 & N.S. & 183.857 \\
\hline YME LSD $_{0.05}$ & 50.404 & 0.115 & 150.129 & 50.404 & 0.115 & 150.129 & & & \\
\hline
\end{tabular}

NLS, HLS, and FLS represent no lateral shoots (no leaf), half lateral shoots (3-4 leaves) full lateral shoots (6-7 leaves). MSME means main shoot main effect, LSME means lateral shoot main effect and YME means year main effect. Different lowercase superscript letters in same column and uppercase letters in same line represent statistically significant differences between means at $p<0.05$ according to least significant difference test. n.s. means not significant

\section{Tartaric acid $(g / L)$}

It was observed that different lateral shoot length and main shoot length applications did not significantly affect the amount of tartaric acid in grape berries in 2014 and 2015. However, in the rainy 2014 year, the year main effect of tartaric acid was found to be $6.28 \mathrm{~g} / \mathrm{L}$, whereas in it was found lower and statistically significant with $4.28 \mathrm{~g} / \mathrm{L}$. the drier and warmer 2015 (Table 7).

Table 7. Effects of main shoot and lateral shoot treatments on tartaric acid, malic acid and potassium

\begin{tabular}{|c|c|c|c|c|c|c|c|c|c|}
\hline \multirow[b]{2}{*}{ Treatments } & \multicolumn{3}{|c|}{2014} & \multicolumn{3}{|c|}{2015} & \multicolumn{3}{|c|}{ Mean of years } \\
\hline & $\begin{array}{c}\text { Tartaric } \\
\operatorname{acid}(\mathrm{g} / \mathrm{L})\end{array}$ & \begin{tabular}{|c|}
$\begin{array}{c}\text { Malic acid } \\
(\mathrm{g} / \mathrm{L})\end{array}$ \\
\end{tabular} & $\begin{array}{c}\text { Potassium } \\
(\mathrm{mg} / \mathrm{L})\end{array}$ & $\begin{array}{c}\text { Tartaric } \\
\operatorname{acid}(\mathrm{g} / \mathrm{L})\end{array}$ & $\begin{array}{c}\text { Malic acid } \\
(\mathrm{g} / \mathrm{L})\end{array}$ & $\begin{array}{c}\text { Potassium } \\
(\mathrm{mg} / \mathrm{L})\end{array}$ & $\begin{array}{c}\text { Tartaric } \\
\operatorname{acid}(g / L)\end{array}$ & \begin{tabular}{|c|}
$\begin{array}{c}\text { Malic acid } \\
(\mathrm{g} / \mathrm{L})\end{array}$ \\
\end{tabular} & $\begin{array}{c}\text { Potassium } \\
(\mathrm{mg} / \mathrm{L})\end{array}$ \\
\hline $1 \mathrm{~m}$ & 6.10 & 1.68 & 2496.28 & 3.56 & 1.20 & 1084.77 & $4.83^{b}$ & 1.44 & 1790.53 \\
\hline $1.25 \mathrm{~m}$ & 6.23 & 1.65 & 2332.11 & 5.34 & 1.05 & 1065.66 & $5.79^{a}$ & 1.35 & 1698.89 \\
\hline $1.5 \mathrm{~m}$ & 6.53 & 1.89 & 2485.08 & 3.92 & 0.88 & 935.99 & $5.22^{b}$ & 1.39 & 1710.34 \\
\hline NLS & 6.27 & 1.53 & 2475.53 & 4.53 & $1.01^{b}$ & 963.26 & 5.40 & $1.27^{b}$ & 1719.40 \\
\hline HLS & 6.25 & 1.93 & 2478.49 & 4.45 & $1.30^{a}$ & 1091.68 & 5.35 & $1.62^{a}$ & 1785.09 \\
\hline FLS & 6.33 & 1.76 & 2359345 & 3.86 & $0.82^{b}$ & 1031.09 & 5.09 & $1.29^{b}$ & 1695.27 \\
\hline YME & $6.28^{A}$ & $1.74^{A}$ & $2437.82^{A}$ & $4.28^{B}$ & $1.05^{B}$ & $1028.67^{B}$ & & & \\
\hline MSME LSD $_{0.05}$ & n.s. & n.s. & n.s. & n.s. & n.s. & n.s. & 0.482 & n.s. & n.s. \\
\hline LSME LSD $_{0.05}$ & n.s. & n.s. & n.s. & n.s. & 0.238 & n.s. & n.s. & 0.179 & n.s. \\
\hline YME LSD 0.05 & 0.453 & 0.138 & 123.45 & 0.453 & 0.138 & 123.45 & & & \\
\hline
\end{tabular}

NLS, HLS, and FLS represent no lateral shoots (no leaf), half lateral shoots (3-4 leaves) full lateral shoots (6-7 leaves). MSME means main shoot main effect, LSME means lateral shoot main effect and YME means year main effect. Different lowercase superscript letters in same column and uppercase letters in same line represent statistically significant differences between means at $p<0.05$ according to least significant difference test. n.s. means not significant

\section{Malic acid $(g / L)$}

Significant differences were found in malic acid amount in lateral shoot practices in 2015. While HLS application reached the highest amount of malic acid with $1.30 \mathrm{~g} / \mathrm{L}$, 
NLS application was measured as $1.01 \mathrm{~g} / \mathrm{L}$ and FLS application was measured as $0.82 \mathrm{~g} / \mathrm{L}$ and they produced different statistic classes. In 2014, no significant differences were found between the practices. As the main effect of the year, in 2015, as in tartaric acid, lower amounts of malic acid were detected (Table 7).

\section{Potassium $(m g / L)$}

One of the prominent features in the determination of maturity is the accumulation of potassium in the skin in parallel with the accumulation of sugar in berry flesh. Although it is one of the most important mineral substances in berry composition, very high potassium levels may decrease quality and may have a negative effect on wine quality especially in red wines (Davies et al., 2006).

It also plays an important role in the rapid phase of the cell division during the first stage of berry development due to the potent role in osmotic regulation. Potassium levels during berry development can be affected by many external factors such as soil, grape variety and cultivation practices (Mpelasoka et al., 2003).

However, although potassium levels were not significantly affected by different main shoot and lateral shoot applications, it was observed that higher potassium accumulation occurred in berries in 2014, when precipitation occurred above normal conditions. However, potassium levels were within the expected values in both years (Table 7).

\section{Conclusion}

As a result, Merlot/5BB combination vines are affected positively in terms of physiological activities and quality criteria when the lateral shoots are kept with 3-4 leaves from the verasion to the harvest in hot years like 2015 (187.40 $\mathrm{mm}$ precipitation, $73.43 \%$ relative humidity, $1243.56 \mu \mathrm{mol} \mathrm{m} / \mathrm{s}$ light intensity) when rainfall and proportional humidity are relatively low in vegetation period. It is recommended that the lateral shoots should be completely removed during verasion to harvest period, in cool years like $2014(475.20 \mathrm{~mm}$ precipitation, $77.53 \%$ relative humidity, $790.31 \mu \mathrm{mol} \mathrm{m} / \mathrm{s}$ light intensity) when vegetation period has high rainfall and proportional humidity and low light intensity.

In terms of main shoot lengths, as the shoot length increases, stress and some quality criteria tend to increase, but these effects are generally not statistically significant. Even when the main shoot length is kept at $1 \mathrm{~m}$, leaf area can reach a sufficient level in terms of yield and quality.

It is considered that future studies should be carried out with modeling studies related to clustermicroclimate, especially with regard to lighting and wind movements within the canopy. In addition, it is considered necessary to transfer green pruning applications to mechanization in practical terms.

Acknowledgements. This study is based on a part of the doctoral thesis of the corresponding author and supported by Republic of Turkey Ministry of Agriculture and Forestry General Directorate of Agricultural Research and Policies with the project number TAGEM/BBAD/2013/A08/P04-08.

\section{REFERENCES}

[1] AOAC (1998): Official Methods of Analysis. - Method 952-03. $16^{\text {th }}$ Ed. Revision. 
[2] Bertamini, M. Nedunchezhian, N. (2003): Photoinhibition of photosynthesis in mature and young leaves of grapevine (Vitis vinifera L.). - Plant Science 164(4): 635-644. doi.org/10.1016/S0168-9452(03)00018-9.

[3] Blouin, J., Guimberteau, G. (2000): Maturation et Maturite des Raisins. - Feret, Bordeaux.

[4] Carbonneau, A., Bahar, E. (2009): Vine and berry responses to contrasted water fluxes in ecotron around 'veraison'. Manipulation of berry shrivelling and consequences on berry growth, sugar loading and maturation. - Proceedings of the $16^{\text {th }}$ International GiESCO Symposium, July 12-15, University of California, Davis, pp. 145-155.

[5] Chacón, J. L., García, E., Martínez, J., Romero, R., Gómez, S. (2009): Impact of the vine water status on the berry and seed phenolic composition of Merlot (Vitis vinifera L.) cultivated in a warm climate: consequence for the style of wine. - Vitis 48(1): 7-9.

[6] Chaves, M. M., Santos, T. P., Souza, C. (2007): Deficit irrigation in grapevine improves water-use efficiency while controlling vigour and production quality. - Annals of Applied Biology 150: 237-252. doi.org/10.1111/j.1744-7348.2006.00123.x.

[7] Crippen, J. R., Morrison, J. C. (1986): The effects of sun exposure on the compositional development of Cabernet Sauvignon berries. - American Journal of Enology and Viticulture 37: 235-242.

[8] Davies, C., Shin, R., Liu, W., Thomas, M. R., Schactman, D. P. (2006): Transporters expressed during grape berry (Vitis vinifera L.) development are associated with an increase in berry size and potassium accumulation. - Journal of Experimental Botany 57: 3209-3216. DOI: 10.1093/jxb/er1091.

[9] Dixon, R. A., Xie, D. Y., Sharma, S. B. (2005): Proanthocyanidins: a final frontier in flavonoid research? - New Phytologist 165: 9-28. DOI: 10.1111/j.14698137.2004.01217.x.

[10] Donat, M. G., Alexander, L. V., Yang, H., Durre, I., Vose, R., Caesar, J. (2013): Global land-based datasets for monitoring climatic extremes. - Bulletin of the American Meteorological Society 94: 997-1006. doi.org/10.1175/BAMS-D-12-00109.1.

[11] Escalona, J., Flexas, J., Medrano, H. (1999): Stomatal and nonstomatal limitations of photosynthesis under water stress in fieldgrown grapevines. - Australian Journal of Plant Physiology 26: 421-433. DOI: 10.1071/PP99019_CO.

[12] Escalona, J., Flexas, J., Bota, J., Medrano, H. (2003): Distribution of leaf photosynthesis and transpiration within grapevine canopies under different drought conditions. - Vitis 42(2): 57-64.

[13] Flexas, J., Escalona, J. M., Medrano, H. (1998): Down-regulation of photosynthesis by drought under field conditions in grapevine leaves. - Australian Journal of Plant Physiology 25: 893-900. DOI: 10.1071/PP98054.

[14] Flexas, J., Medrano, H., Escalona, J. M., Bota, J., Gulias, J. (2002): Regulation of photosynthesis of $\mathrm{C} 3$ plants in response to progressive drought: stomatal conductance as a reference parameter. - Annals of Botany 89: 895-905. DOI: 10.1093/aob/mcf079.

[15] Fraga, H., Malheiro, A. C., Moutinho-Pereira, J., Santos, J. A. (2012): An overview of climate change impacts on European viticulture. - Food and Energy Security 1(2): 94110. doi.org/10.1002/fes3.14.

[16] German, J. B., Walzem, R. L. (2000): The health benefits of wine. - Annual Review of Nutrition 20: 561-593. doi.org/10.1146/annurev.nutr.20.1.561.

[17] Haselgrove, L., Botting, D., van Heeswijck, R., Hoj, P. B., Dry, P. R., Ford, C., Iland, P. G. (2000): Canopy microclimate and berry composition: the effect of bunch exposure on the phenolic composition of Vitis vinifera L. cv. Shiraz grape berries. - Australian Journal of Grape and Wine Research 6: 141-149. doi.org/10.1111/j.1755-0238.2000.tb00173.x.

[18] Jones, G. V. (2007): Climate change: observations, projections, and general implications for viticulture and wine production. - OIV Climate and Viticulture Congress, April 1014, Spain. 
[19] Kataoka, I., Kubo, Y., Sugiura, A., Tomana, T. (1984): Effects of temperature, cluster shading and some growth regulators on 1-phenylalanine ammonia-lyase activity and anthocyanin accumulation in black grapes. - Memoirs of the College of Agriculture/Agronomy and Horticultural Science Series 124: 35-44.

[20] Keller, M. (2010): The Science of Grapevines, Anatomy and Physiology. $1^{\text {st }}$ Ed. Academic Press, Cambridge, MA.

[21] Kliewer, W. M. (1965): Changes in the concentration of malates, tartrates, and total free acids in flowers and berries of Vitis Vinifera. - American Journal of Enology and Viticulture 16: 92-100.

[22] Kliewer, W. M. (1970): Effect of day temperature and light intensity on coloration of Vitis vinifera grapes. - Journal of the American Society for Horticultural Science 95: 693697.

[23] Kliewer, W. M. (1973): Berry composition of Vitis vinifera cultivars as influenced by photo temperatures and nycto-temperatures during maturation. - Journal of the American Society for Horticultural Science 98: 153-159.

[24] Lorenz, D., Eichhorn, K., Bleiholder, H., Klose, R., Meier, U., Weber, E. (1995): Phenological growth stages of the grapevine (Vitis vinifera $\mathrm{L}$. ssp. vinifera)-codes and descriptions according to the extended $\mathrm{BBCH}$ scale. - Australian Journal of Grape and Wine Research 1: 100-110. doi.org/10.1111/j.1755-0238.1995.tb00085.x.

[25] Matthews, M., Ishii, R., Anderson, M., O'mahony, M. (1990): Dependence of wine sensory attributes on vine water status. -Journal of Science, Food and Agriculture 51: 321-335. doi.org/10.1002/jsfa.2740510305.

[26] Maroco, J. P., Rodrigues, M. L., Lopes, C., Chaves, M. M. (2002): Limitations to leaf photosynthesis in field-grown grapevine under drought. Metabolic and modelling approaches. - Functional Plant Biology 29: 451-459. DOI: 10.1071/PP01040.

[27] Medrano, H., Escalona, J. M., Cifre, J., Bota, J., Flexas, J. (2003): A ten-year study on the physiology of two spanish grapevine cultivars under field conditions: effects of water availability from leaf photosynthesis to grape yield and quality. - Functional Plant Biology 30(6): 607-619. doi.org/10.1071/FP02110.

[28] Mori, K., Sugaya, S., Gemma, H. (2004): Regulatory mechanism of anthocyanin biosynthesis in 'Kyoho' grape berries grown under different temperature conditions. Environmental Control in Biology 42: 21-30. DOI: 10.2525/ecb1963.42.21.

[29] Morris, J. R., Sims, C. A., Cawthon, D. L. (1983): Effects of excessive potassium levels on ph, acidity and color of fresh and stored grape juice. - American Journal of Enology and Viticulture 34: 35-39.

[30] Mpelasoka, B. S., Schachtman, D. P., Treeby, M. T., Thomas, M. R. (2003): A review of potassium nutrition in grapevines with special emphasis on berry accumulation. Australian Journal of Grape and Wine Research 9: 154-168. DOI: 10.1111/J.17550238.2003.Tb00265.x.

[31] Nemani, R. R., White, M. A., Cayan, D. R., Jones, G. V., Runnin, S. W., Coughlan, J. C. (2001): Asymmetric climatic warming improves California vintages. - Climate Research 19(1): 25-34.

[32] OIV (2012): Compendium of International Methods of Wine and Musts. Vol. 1-2. - OIV, Paris.

[33] Olsen, J. L., Olesen, A., Breuning-Madsen, H., Balstrom, T. (2011): A method to identify potential cold-climate vine growing sites. A case study from Rosnaes in Denmark. Danish Journal of Geography 111: 73-84.

[34] Profio, F. D., Reynolds, A. G., Kasimos, A. (2011): Canopy management and enzyme impacts on Merlot, Cabernet Franc and Cabernet Sauvignon. II. Yield and berry composition. - American Journal of Enology and Viticulture 62(2): 152-168. DOI: 10.5344/ajev.2010.10024.

[35] Reynolds, A. G., Pool, R. M., Mattick, L. R. (1986): Influence of cluster exposure on fruit composition and wine quality of Seyyal Blanc grapes. - Vitis 25: 85-95. 
[36] Ribéreau-Gayon, P., Glories, Y., Maujean, A., Dubourdieau, D. (2000): Handbook of Enology. Vol. 2: The Chemistry of Wine and Stabilization and Treatments. - John Wiley and Sons Ltd, Chichester.

[37] Roby, G., James, F., Douglas, A., Adams, A., Mark, A. (2004): Berry size and vine water deficits as factors in winegrape composition: anthocyanins and tannins. - Australian Journal of Grape and Wine Research 10: 100-107. doi.org/10.1111/j.17550238.2004.tb00012.x.

[38] Rojas-Lara, B. A., Morrison, J. C. (1989): Differential effects of shading fruit or foliage on the development and composition of grape berries. - Vitis 28(4): 199-208.

[39] Romero, P., Fernández-Fernández, J. I., Cutillas, A. (2010): Physiological thresholds for efficient regulated deficit-irrigation management in winegrapes grown under semiarid conditions. - American Journal of Enology and Viticulture 61: 300-312.

[40] Ruffner, H. P. (1982): Metabolism of tartaric and malic acids in Vitis. A review. - Vitis 21: 346-358.

[41] Santos, T., Lopes, C. M., Rodrigues, M. L., Souza, C. R., Maroco, J., Pereira, J. S., Silva, J. R., Chaves, M. M. (2007): Partial rootzone drying irrigation affects cluster microclimate improving fruit composition of 'Moscatel' field-grown grapevines. Scientia Horticulturae 112: 321-330. DOI: 10.1071/FP02180.

[42] Schubert, A., Restagno, M., Lovisolo, C. (1996): Net photosynthesis of grapevine leaves of different age exposed to high or low light intensities. - Advances in Horticultural Science 10(3): 163-166.

[43] Schultz, H. R. (2000): Climate change and viticulture: a European perspective on climatology, carbon dioxide and UV-B effects. - Australian Journal of Grape and Wine Research 6: 2-12. doi.org/10.1111/j.1755-0238.2000.tb00156.x.

[44] Smart, R. E., Dick, J. K., Gravett, I. M., Fisher, B. M. (1990): Canopy management to improve grape yield and wine quality-principles and practices. - South African Enology and Viticulture 11(1): 3-17. doi.org/10.21548/11-1-2232.

[45] Spayd, S. E., Tarara, J. M., Mee, D. L., Ferguson, J. C. (2011): Separation of sunlight and temperature effects on the composition of Vitis vinifera cv. Merlot berries. - American Journal of Enology and Viticulture 53: 171-182.

[46] Sweetman, C. V., Sadras, O., Hancock, R. D., Soole, K. L., Ford, C. M. (2014): Metabolic effects of elevated temperature on organic acid degradation in ripening Vitis vinifera. - Fruit Journal of Experimental Botany 65(20): 5975-5988. DOI: 10.1093/jxb/eru343.

[47] Taiz, L., Zeiger, E. (2010): Plant Physiology. $5^{\text {th }}$ Ed. - Sinauer Associates, Sunderland, MA.

[48] This, P., Lacombe, T., Thoma, M. R. (2006): Historical origins and genetic diversity of wine grapes. - Trends in Genetics 22: 511-519. DOI: 10.1016/j.tig. 2006.07.008.

[49] Tomana, T., Utsunomiya, N., Kataoka, I. (1979): The effect of environmental temperature on fruit ripening on the tree. II. The effect of temperatures around whole vines and clusters on the coloration of 'Kyoho' grapes. - Journal of the Japanese Society for Horticultural Science 48: 261-266.

[50] Treutter, D. (2010): Managing phenol contents in crop plants by phytochemical farming and breeding-visions and constraints. - International Journal of Molecular Sciences 11(3): 807-857. dx.doi.org/10.3390/ijms11030807.

[51] Vrsic, S., Vodovnik, T. (2012): Reactions of grape varieties to climate changes in North East Slovenia. - Plant Soil and Environment 58: 34-41. DOI: 10.17221/352/2011-PSE.

[52] Waterhouse, A. L. (2002): Determination of total phenolics. - Current Protocols in Food Analytical Chemistry. https://doi.org/10.1002/0471142913.fai0101s06.

[53] Webb, L. B., Whetton, P. H., Barlown, E. W. R. (2008): Climate change and wine grape quality in Australia. - Climate Research 36: 99-111.

[54] Yasasin, A. S., Bahar, E., Boz, Y., Kiraci, M. A., Gündüz, A., Avcı, G. G., Gülcü, M. (2018): Different soil tillage and shoot length effects on vegetative growth, water stress 
and yield in cv. Cabernet Sauvignon (Vitis vinifera L.). - I. International Agricultural Science Congress. 9-12 May 2018, Van, Turkey.

[55] Yamane, T., Shibayama, K. (2006): Effects of changes in the sensitivity to temperature on skin coloration in 'Aki Queen' grape berries. - Journal of the Japanese Society for Horticultural Science 75: 458-462. 